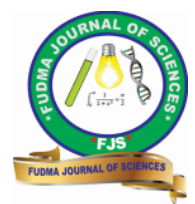

FUDMA Journal of Sciences (FJS)

ISSN online: $2616-1370$

ISSN print: 2645 - 2944

Vol. 4 No. 3, September, 2020, pp $292-299$

DOI: https://doi.org/10.33003/fjs-2020-0403-298

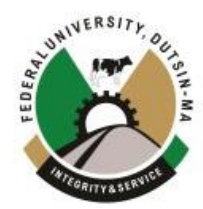

\title{
EFFECT OF IRRIGATION REGIMES ON YIELD AND WATER USE EFFICIENCY OF EXTRA-EARLY MAIZE VARIETY IN KANO RIVER IRRIGATION PROJECT
}

\author{
${ }^{1}$ M. Lawal, ${ }^{2}$ M. A. Oyebode and ${ }^{3} J$. Suleiman
}

\begin{abstract}
${ }^{1}$ Federal Ministry of Agriculture and Rural Development, Abuja- Nigeria
${ }^{2}$ Department of Agricultural Engineering, Faculty of Engineering, Ahmadu Bello University Zaria, Kaduna,Nigeria

${ }^{3}$ Department of Crop Production and Protection, Faculty of Agriculture and Agricultural Technology, Federal University Dutsin-ma, Nigeria
\end{abstract}

Corresponding Author's email: lawalmubarak77@gmail.com

\begin{abstract}
A field experiment was conducted to evaluate the effect of irrigation regimes on yield and water use efficiency of maize crop (Zea Mays L.; SAMMAZ 29) under different irrigation scheduling. Randomized Complete Block Design (RCBD) was used and the experiment consisted of three levels of irrigation water application depth of $100 \%, 75 \%$ and $50 \%$ replacement of Total Available Water Capacity (TAWC) and three irrigation intervals of 7, 10 and 13 days replicated three times. Irrigation water was applied into each of 0.75 $\mathrm{m} \times 90 \mathrm{~m}$ furrow using siphon tube of $7.5 \mathrm{~cm}$ diameter and $200 \mathrm{~cm}$ length. The results showed that the highest average irrigation water use efficiency was at $\mathrm{I}_{10} \mathrm{D}_{75} \%$ with $0.71 \mathrm{~kg} / \mathrm{m}^{3}$ while the least was at $\mathrm{I}_{13} \mathrm{D}_{50 \%}$ with $0.41 \mathrm{~kg} / \mathrm{m}^{3}$. The highest average crop water use efficiency (CWUE) was at $\mathrm{I}_{10} \mathrm{D}_{75 \%}$ with $0.79 \mathrm{~kg} / \mathrm{m}^{3}$ while the least was at $\mathrm{I}_{13} \mathrm{D}_{75} \%$ with $0.56 \mathrm{~kg} / \mathrm{m}^{3}$. The highest average maize yield was at $\mathrm{I}_{7} \mathrm{D}_{100 \%}$ with 3580 $\mathrm{kg} / \mathrm{ha}$ while the least was at $\mathrm{I}_{13} \mathrm{D}_{50} \%$ with $1200 \mathrm{~kg} / \mathrm{ha}$. The study established that irrigation after every 10 days interval with $75 \%$ replacement of TAWC using furrow irrigation of $90 \mathrm{~m}$ lengths produced the highest crop water use efficiency, thus saving about $48.3 \%$ of irrigation water (amounting to $329 \mathrm{~mm}$ ) with reference to control $\left(\mathrm{I}_{7} \mathrm{D}_{100 \%}\right)$ which causes a yield reduction of about $19 \%$ (amounting to $680 \mathrm{~kg} / \mathrm{ha}$ ). This efficient water usage saved cost and also helps to address the problem of high water table of the study area.
\end{abstract}

Keywords: Maize variety, yield, irrigation depth and interval, furrow irrigation.

\section{INTRODUCTION}

Proper irrigation water management plays a vital role in sustainability of agriculture. Continues declining of water resources and increasing in food demand necessitate achieving greater efficiency in water use at both rainfed and irrigated agriculture (Smith and Kivumbi, 2002).

Irrigation scheduling is the decision of when and how much water to apply to a field in order to maximize profit (Tariq and Usman, 2009). Its purpose is to maximize irrigation efficiencies by applying the exact amount of water needed to replenish the In a majority of irrigation schemes in Nigeria, water is not a soil moisture to the desired level, thus saves water and energy. limiting factor; rather the abundance of water is a problem It minimizes water-logging problems by reducing the drainage which results in over irrigation because of abundance water requirements and control root zone salinity problems through (Sani et al., 2008). Research had shown that, on each irrigation controlled leaching (Tariq and Usman, 2009). Water use efficiency is a general factor in the field of harmful to crops because it retards proper growth and agricultural researches, which provides information about the subsequent yield (Sani et al., 2008). Many work conducted at relation between grain yield and plant water consumption Kadawa indicated that best yield of maize was obtained by (Yahya et. al. 2011). Irrigation water use efficiency (IWUE) is adopting the conventional 7 day interval (Mani and Dadari, used to describe the relationship between crop yields and the 2003), which contributed to the rise of ground water table due total depth of water applied during the growing period, while to frequent irrigation application. The increase in irrigation crop water use efficiency is mostly used to describe irrigation frequency may result in an unacceptable increase in depth of effectiveness in terms of crop yield (Netafim, 2010). Improving water applied, a corresponding decrease in water use efficiency in water use efficiency can be achieved through the and consequent drainage problems as a result of high water development of new irrigation scheduling techniques such as table (FAO, 2013). Detailed information is therefore needed in deficit irrigation (Bekele and Tilahun, 2007). Extra early maize order to provide farmers with an efficient method of water variety also known as SAMMAZ 29 is an open pollinated management that will reduce the wastage of water by farmers, 
thus helping farmers to control the quantity and timing of water water use efficiency of extra-early maize variety using furrow delivery to align water application with the plant water use and irrigation in Kano river irrigation project.

most sensitive growing periods.

The objective of this research was to determine the effect of different irrigation intervals and irrigation depths on yield and

\section{MATERIALS AND METHOD}

The study was conducted at the Irrigation Research Station of the Institute for Agricultural Research Kadawa in Kano River Irrigation Project, Garun- Mallam Local Government area of Kano State. The Kano River Irrigation Project is one of the largest irrigation projects in Nigeria which lies between latitude $11^{\circ} 30^{\prime}$ to $12^{\circ} 03^{\prime} \mathrm{N}$, longitude $08^{\circ} 30^{\prime}$ to $09^{\circ} 40^{\prime} \mathrm{E}$ and $486 \mathrm{~m}$ above sea level within the Hadejia Jama'are River Basin, covering an area of about 75, 000 hectares. The average weather data of the study site are presented in Table 1.

Table 1. Average Weather data for the study period in 2013/2014 dry season

\begin{tabular}{lllll}
\hline \multirow{2}{*}{ Parameter } & \multicolumn{1}{c}{$\mathbf{1 5}^{\text {th }}$} & Month & $\mathbf{1 5}^{\text {th }}$ \\
\cline { 2 - 5 } & & & & \\
& February & March & April & May \\
\hline Maximum Temperature $\left({ }^{\circ} \mathrm{C}\right)$ & 34.4 & 36.2 & 38.2 & 36.5 \\
Minimum Temperature $\left({ }^{\circ} \mathrm{C}\right)$ & 20.6 & 22.4 & 26.1 & 23.9 \\
Relative humidity $(\%)$ & 24 & 21 & 32 & 31 \\
Wind speed (km/day) & 162 & 189 & 197 & 181 \\
Sunshine hour (hr) & 11.1 & 12.0 & 10.9 & 11.3 \\
\hline
\end{tabular}

Source: meteorological station of Kadawa irrigation research station.

\section{Soil Physical Properties}

The physical properties of the soil at the experimental field were determined through soil sampling and were taken to the Soil Laboratory for analysis. An effective root depth of $0.75 \mathrm{~m}$ $(75 \mathrm{~cm})$ was considered for maize crop in this study as recommended by Andreas and Karen (2002) and Hussaini et al.,(2008) at an incremental depths of $0-20 \mathrm{~cm}, 20-40 \mathrm{~cm}$ and $40-75 \mathrm{~cm}$.

Soil samples were taken from 3 selected points, the moisture content at both field capacity and wilting point condition were determined using pressure plate apparatus while the soil bulk densities were determined through oven-dry method. For the purpose of textural classification, the percentages of silt, clay and sand, were determined by hydrometer method using USDA soil texture classification where individual soil samples were taking at $0-20,20-40$, and $40-75 \mathrm{~cm}$ depth along the soil profile from the 3 selected points. The dominant texture class of soil was sandy loam for the entire experimental plots. Table 2 presents the soil physical properties of the soil the experimental site.

Table 2. Soil Physical Properties at the experimental site

\begin{tabular}{rllllllll}
\hline DEPTH $(\mathrm{cm})$ & $\begin{array}{l}\text { FC(\%) } \\
0.33 \text { bar }\end{array}$ & $\begin{array}{l}\text { PWP } \\
15 \text { bar }\end{array}$ & $\begin{array}{l}\text { BULK } \\
\text { DENSITY } \\
\left(\mathrm{g} / \mathrm{cm}^{3}\right)\end{array}$ & CLAY $(\%)$ & SILT (\%) & $\begin{array}{l}\text { SAND } \\
(\%)\end{array}$ & $\begin{array}{l}\text { TEXTURAL } \\
\text { CLASS }\end{array}$ \\
$0-20$ & 35.80 & 6.53 & 1.54 & 1.56 & 16 & 70 & SANDY LOAM \\
$20-40$ & 37.27 & 8.87 & 1.50 & 18 & 16 & 66 & SANDY LOAM \\
$40-75$ & 39.60 & 10.10 & 18 & 18 & 64 & SANDY LOAM \\
\hline
\end{tabular}

\section{Experimental Design and Treatments Description}

The experiment consisted of three (3) levels of irrigation interval (7, 10 and 13 days) and three (3) levels of irrigation depths (Replacements of $100 \%, 75 \%$ and $50 \%$ of Total Available Water Capacity, TAWC), which make a total of nine (9) treatments. The experimental treatments were replicated 3 times, making a total of 27 experimental plots considered, laid in RANDOMIZED COMPLETE BLOCK DESIGN, (RCBD). 
Table 3: Description of the experimental treatments

\begin{tabular}{ll}
\hline Treatment labels & Treatment Description \\
\hline $\mathrm{I}_{7} \mathrm{D}_{100 \%}$ & 7 day Irrigation Interval with $100 \%$ Replacement of Total Available Water Capacity \\
$\mathrm{I}_{7} \mathrm{D}_{75 \%}$ & 7 day Irrigation Interval with $75 \%$ Replacement of Total Available Water Capacity \\
$\mathrm{I}_{7} \mathrm{D}_{50 \%}$ & 7 day Irrigation Interval with $50 \%$ Replacement of Total Available Water Capacity \\
$\mathrm{I}_{10} \mathrm{D}_{100 \%}$ & 10 day Irrigation Interval with $100 \%$ Replacement of Total Available Water Capacity \\
$\mathrm{I}_{10} \mathrm{D}_{75 \%}$ & 10 day Irrigation Interval with $75 \%$ Replacement of Total Available Water Capacity \\
$\mathrm{I}_{10} \mathrm{D}_{50 \%}$ & 13 day Irrigation Interval with $50 \%$ Replacement of Total Available Water Capacity \\
$\mathrm{I}_{13} \mathrm{D}_{100 \%}$ & 13 day Irrigation Interval with $75 \%$ Replacement of Total Available Water Capacity \\
$\mathrm{I}_{13} \mathrm{D}_{75 \%}$ & 13 day Irrigation Interval with $50 \%$ Replacement of Total Available Water Capacity \\
$\mathrm{I}_{13} \mathrm{D}_{50 \%}$ &
\end{tabular}

\section{Field Layout}

A total area of $37 \mathrm{~m} \times 100 \mathrm{~m}$ was used as the experimental field. The field was divided into three blocks as (REP. 1, REP. 2 and REP. 3), each measuring $10.75 \mathrm{~m} \times 100 \mathrm{~m}$. On each replication, there were nine experimental treatments. The length of furrow (L) was $90 \mathrm{~m}$, while the spacing of the furrow (W) was $0.75 \mathrm{~m}$. The furrow had a ' $\mathrm{V}$ ' shape with an average depth of $15 \mathrm{~cm}$ and width of $65 \mathrm{~cm}$ at the top. A buffer space of $2 \mathrm{~m}$ was considered between the replications while $0.5 \mathrm{~m}$ space was considered between the treatments in order to minimize the risk of moisture entry between the treatments.

\section{Agronomic practice}

An extra-early maize variety (SAMMAZ 29) obtained from the Seed Production Unit of Institute for Agricultural Research Zaria was planted manually on the 15 February, 2014 at the rate of 2 seeds per hole at $0.2 \mathrm{~m}$ seed spacing and with $0.75 \mathrm{~m}$ row spacing. Two weeks after planting, the plants were thinned to one plant per stand thereby having an average plant population of 6 plants $/ \mathrm{m}^{2}(66,666$ plants/ha) on each of the experimental treatments. Plants were irrigated uniformly until 3 Weeks After Planting (WAP) when the irrigation treatments were imposed on each plot. A weekly irrigation interval as recommended by Mani and Dadari (2003) and commonly used by the farmers for maize crop in the area was adopted based on $100 \%$ replacement of evapotranspiration losses before imposing experimental treatments, this enables the plant to become fully established. Furrow method of irrigation which is commonly used for row crops in the area was used to apply water to the plants. On each of the experimental plot, nine (9) no. access tubes were installed for moisture measurement along the furrow length, three each at upper, mid and lower end of the furrow. An effective root depth of $0.75 \mathrm{~m}(75 \mathrm{~cm})$ was considered for maize crop in this study as recommended by Andreas and Karen (2002) and Hussaini et al.,(2008) at an incremental depths of $0-20 \mathrm{~cm}, 20-40 \mathrm{~cm}$ and $40-75 \mathrm{~cm}$. So, the soil moisture measurements were taken at depths of $0-20$,
20-40 and $40-75 \mathrm{~cm}$ through the soil profile. Pre-emergence herbicides were used to control weeds. Atrazine was applied at rate of $0.25 \mathrm{~kg} / \mathrm{ha}$ on third day after planting using knapsacks sprayer, followed by hand weeding on seven and nine week after planting on the experimental treatments (Ramesh and Nadanassababady, 2005). Compound fertilizer NPK 15:15:15 and urea $(46 \% \mathrm{~N})$ were applied at three and six weeks after sowing, respectively by placing in a hole and covered with soil to minimize lost and allow efficient use by the plants (Jaliya et al., 2008). The maize (SAMMAZ 29; an extra early variety) was harvested on the 15 May, 2014 after 85 days using hand when it cobs dried and the leaf sheaths have turned brown. It was then threshed and weighed.

\section{Irrigation Water Application}

Siphon tube of $7.5 \mathrm{~cm}$ diameter and $200 \mathrm{~cm}$ long was used to convey water into the furrows. Discharges from the siphon tube were cut-off as soon as the required amount of water was applied. The discharge through the siphon tube into the furrow was computed using equation.

$\mathrm{Q}=\mathrm{AV}$

Where A was the cross-sectional area of the siphon $\left(\mathrm{m}^{2}\right)$ and V was the velocity of flow $(\mathrm{m} / \mathrm{s})$

The cross-sectional area was determined using equation

$\mathrm{A}=\pi\left(\frac{d}{2}\right)^{2}$

Where $\mathrm{d}$ was the Diameter of the tube $(\mathrm{m})$

The velocity of flow was determined using equation

$\mathrm{V}=c_{d} * \sqrt{2 g h}$

Where $g$ was the Acceleration due to gravity $\left(\frac{m^{2}}{s}\right), c_{d}$ was the Coefficient of discharge and $\mathrm{h}$ was the Hydraulic head. The 
coefficient of discharge from the siphon was determined experimentally using volumetric method of determining discharge with a known volume of container.

$$
C_{d}=\frac{4 Q}{\pi d^{2} \sqrt{2 g h}}
$$

\section{Irrigation Time}

The irrigation duration for each of the treatment was determined using the relation as recommended by Michael, (1978) as expressed in equation (5).

$t=\frac{W L d}{360 Q}$

Where $\mathrm{t}$ was the Irrigation duration (elapsed time) in hours, $\mathrm{Q}$ weight of the harvested maize was obtained by weighing the was the Stream size $\left(\mathrm{m}^{3} / \mathrm{s}\right)$, W was the Furrow spacing $(\mathrm{m})$, L threshed maize (dry matter yield at $15 \%$ moisture content) on a was the Furrow lengths (m) and d was the depths of water (m)

\section{Soil moisture measurement}

The soil moisture contents of the experimental plots were monitored throughout the growing season using Soil moisture meter (PMS-714) at three different points along the furrow length, representing the upper end, middle and the lower end of the furrow. At each point, soil moistures were taken through an effective root zone depth of $75 \mathrm{~cm}$, at incremental depths of 0 $20 \mathrm{~cm}, 20-40 \mathrm{~cm}, 40-75 \mathrm{~cm}$, before and after irrigation, as suggested by Merriam and Keller (1978).

\section{Determination of Crop Water Use}

The amount of moisture used by the crop on each irrigation event was estimated from the soil moisture content measurements made two days after irrigation and just before the next irrigation using Equation 6, given as (Michael, 1999).

$$
\mathrm{CWU}=\frac{\sum_{i=1}^{n}\left(\left\langle\mathrm{MC}_{2 \mathrm{i}}-\mathrm{MC}_{1 \mathrm{i}}\right\rangle \mathrm{BD} * \mathrm{D}_{\mathrm{i}}\right)}{t}
$$

Where CWU was the Crop Water Use (mm), $\mathrm{MC}_{1 \mathrm{i}}$ was the Soil moisture content $(\%)$ at the time of first sampling in the $i_{\text {th }}$ soil layer, $\mathrm{MC}_{2 \mathrm{i}}$ was the Soil moisture content (\%) at the time of second in the $i_{\text {th }}$ Soil layer sampling, $D_{i}$ was the depth of ith soil layer $(\mathrm{cm})$, BD was the Bulk density of soil $\left(\mathrm{g} / \mathrm{cm}^{3}\right), \mathrm{n}$ was the number of soil layers sampled in the root zone depth $\mathrm{D}$ and $t$ was the number of days between successive soil moisture content sampling.

\section{Total Available Water Capacity}

The Total Available Water Capacity (TAWC) in the root zone was estimated as the difference between the water content at the field capacity and permanent wilting point. The TAWC was determined on each treatment before irrigation (moisture content at permanent wilting point) and two days after irrigation (moisture content at field capacity) using Soil moisture meter; (PMS-714) as shown in the equation

$$
\mathrm{TAWC}=\sum_{\mathrm{i}=1}^{\mathrm{n}}\left(\left[1000\left(\theta_{\mathrm{FCi}}-\theta_{\mathrm{WPi}}\right) * \mathrm{Z}_{\mathrm{ri}}\right]\right)
$$

Where TAWC was the Total Available Water Capacity (mm), $\theta_{\mathrm{FCi}}$ was the Soil Moisture Content at Field Capacity $\left(\frac{\mathrm{m}^{3}}{\mathrm{~m}^{3}}\right)$ in the ith soil layer, $\theta_{\mathrm{wpi}}$ was the Soil Moisture Content at Permanent Wilting Point $\left(\frac{\mathrm{m}^{3}}{\mathrm{~m}^{3}}\right)$ in the ith soil layer and $\mathrm{Z}_{\mathrm{ri}}$ was the Effective Root Zone Depth (m) of ith soil layer.

\section{Estimation of Crop Yield}

The plant was hand harvested when a visual inspection indicated that $95 \%$ of the plant reached maturity, then it cobs dried and the leaf sheaths have turned brown. The yield of maize per experimental plot was determined first by threshing the maize separately as well as weighing it. It was then converted into kilogram per hectare using equation (8). The weighing balance, while the area of the plot was determined by multiplying the length and width of the plot.

Crop yield $\left(\frac{K g}{h a}\right)=\frac{10,000 *(\text { weight of harvested maize }}{\text { (crop area })}$

\section{Computation of Water Use Efficiency}

Two (2) distinct terms are used in expressing water use efficiency (Michael, 2009).

The Crop Water Use Efficiency (CWUE) was computed using the equation

$C W U E=\frac{Y}{E T_{C}}$

Where $\mathrm{Y}$ was the Crop yield $(\mathrm{kg} / \mathrm{ha})$ and $\mathrm{ET}_{\mathrm{c}}$ was the Total amount of water used in evapotranspiration $(\mathrm{mm})$.

The Irrigation Water Use Efficiency (IWUE) was computed using the equation

$I W U E=\frac{Y}{Q_{f}}$

Where $\mathrm{Q}_{\mathrm{f}}$ was the Total amount of water used in the field (mm) and $\mathrm{Y}$ was the Yield ( $\mathrm{kg} / \mathrm{ha})$.

All data collected were subjected to statistical analysis of variance (ANOVA). Treatment means and significant differences were calculated using least significant difference method (LSD).

\section{RESULTS AND DISCUSSION \\ RESULT}

Effect of irrigation depths and irrigation intervals on maize yield

Table 4 shows the effect of irrigation depths and irrigation intervals on maize yield, which was highly significant at $\mathrm{P}<$ 0.01 levels. Increase in irrigation depth from $50 \%$ to $100 \%$ significantly increased the maize yield. However, increase in irrigation intervals from 7 days to 13 days significantly decreased the maize yield. 
Table- 4. Effect of irrigation depth and irrigation interval on maize yield, crop water use efficiency and irrigation water use efficiency at Kadawa in 2013/2014 dry season

\begin{tabular}{|c|c|c|c|}
\hline Treatment & Maize Yield (t/ha) & $\begin{array}{c}\text { Crop water use } \\
\text { efficiency }\left(\mathrm{kg} / \mathrm{m}^{3}\right)\end{array}$ & $\begin{array}{l}\text { Irrigation water use } \\
\text { efficiency }\left(\mathrm{kg} / \mathrm{m}^{3}\right)\end{array}$ \\
\hline \multicolumn{4}{|c|}{ Irrigation depths } \\
\hline $\mathrm{D}_{100 \%}$ & $2.837 \mathrm{a}$ & $0.697 \mathrm{a}$ & $0.570 \mathrm{a}$ \\
\hline $\mathrm{D}_{75 \%}$ & $2.463 b$ & $0.697 \mathrm{a}$ & $0.593 \mathrm{a}$ \\
\hline $\mathrm{D}_{50 \%}$ & $2.030 \mathrm{c}$ & $0.657 \mathrm{a}$ & $0.540 \mathrm{~b}$ \\
\hline $\mathrm{CV}$ & 6.753 & 8.305 & 6.279 \\
\hline \multicolumn{4}{|c|}{ Irrigation interval } \\
\hline 7- days & $3.32 \mathrm{a}$ & $0.737 \mathrm{a}$ & $0.577 b$ \\
\hline 10- days & $2.513 b$ & $0.727 \mathrm{a}$ & $0.663 \mathrm{a}$ \\
\hline 13-days & $1.497 \mathrm{c}$ & $0.587 b$ & $0.463 \mathrm{c}$ \\
\hline $\mathrm{CV}$ & 6.753 & 8.305 & 6.279 \\
\hline \multicolumn{4}{|c|}{ INTERACTION } \\
\hline DxI & NS & NS & $* *$ \\
\hline
\end{tabular}

A non significant Interaction between irrigation depths and irrigation intervals on maize yield was observed (Table 5). When the irrigation interval was fixed, irrigation intervals at 7 day and 10 day revealed that increase in irrigation depth from $50 \%$ to $75 \%$ irrigation depths significantly increased the maize yield while irrigation at 13 day had no any significant effect on the maize yield. Further increase to $100 \%$ irrigation depths had no significant effect on the maize yield at 7 day irrigation interval while it revealed a significant increased on the yield at 10 day and 13 day irrigation intervals. But when irrigation depths was fixed, all the irrigation depths revealed that increase in irrigation interval from 7 days to 13 days significantly reduced the maize yield. The highest maize yield was at $\mathrm{I}_{7} \mathrm{D}_{100 \%}$ with $3.58 \mathrm{t} /$ ha while the least was at $\mathrm{I}_{13} \mathrm{D}_{50} \%$ with $1.2 \mathrm{t} / \mathrm{ha}$. 
Table- 5. Interaction of irrigation depths and irrigation intervals on maize yield, crop water use efficiency and irrigation water use efficiency at Kadawa in 2013/2014 dry season

\begin{tabular}{|c|c|c|c|}
\hline \multirow{2}{*}{ Treatment } & \multicolumn{3}{|c|}{ Irrigation interval } \\
\hline & 7- Days & 10- Days & 13- Days \\
\hline Irrigation depths & \multicolumn{3}{|c|}{ Maize yield (t/ha) } \\
\hline $\mathrm{D}_{100 \%}$ & $3.580 \mathrm{a}$ & $3.080 \mathrm{~b}$ & $1.850 \mathrm{~d}$ \\
\hline $\mathrm{D}_{75 \%}$ & $3.450 \mathrm{a}$ & $2.500 \mathrm{c}$ & $1.440 \mathrm{e}$ \\
\hline $\mathrm{D}_{50 \%}$ & $2.930 \mathrm{~b}$ & $1.960 \mathrm{~d}$ & $1.200 \mathrm{e}$ \\
\hline \multirow[t]{2}{*}{$\mathrm{CV}$} & \multicolumn{3}{|c|}{6.753} \\
\hline & \multicolumn{3}{|c|}{ Crop water use efficiency $\left(\mathrm{kg} / \mathrm{m}^{3}\right)$} \\
\hline $\mathrm{D}_{100 \%}$ & $0.740 \mathrm{ab}$ & $0.74 \mathrm{ab}$ & $0.610 \mathrm{c}$ \\
\hline $\mathrm{D}_{75 \%}$ & $0.740 \mathrm{ab}$ & $0.790 \mathrm{a}$ & $0.560 \mathrm{c}$ \\
\hline $\mathrm{D}_{50 \%}$ & $0.730 \mathrm{ab}$ & $0.650 \mathrm{bc}$ & $0.590 \mathrm{c}$ \\
\hline \multirow[t]{2}{*}{$\mathrm{CV}$} & \multicolumn{3}{|c|}{8.305} \\
\hline & \multicolumn{3}{|c|}{ Irrigation water use efficiency $\left(\mathrm{kg} / \mathrm{m}^{3}\right)$} \\
\hline $\mathrm{D}_{100 \%}$ & $0.530 \mathrm{de}$ & $0.660 \mathrm{ab}$ & $0.520 \mathrm{ef}$ \\
\hline $\mathrm{D}_{75 \%}$ & $0.610 \mathrm{bc}$ & $0.710 \mathrm{a}$ & $0.460 \mathrm{fg}$ \\
\hline $\mathrm{D}_{50 \%}$ & $0.590 \mathrm{~cd}$ & $0.620 \mathrm{bc}$ & $0.410 \mathrm{~g}$ \\
\hline $\mathrm{CV}$ & & 6.279 & \\
\hline
\end{tabular}

Effect of irrigation depths and irrigation intervals on crop water use efficiency

The effect of irrigation depths and irrigation interval on Crop Water Use Efficiency (CWUE) was presented in Table 4. Increase in irrigation depths from $50 \%$ to $100 \%$ had no any significant effect on the CWUE. Increase in irrigation from 7 day to 10 days had no any significant effect on the CWUE while further increase to 13 day irrigation interval recorded a significant reduction in CWUE.

A non significant interaction between irrigation depth and irrigation interval on CWUE was observed (Table 5). When irrigation interval was fixed, irrigation interval at 7 and 13 days revealed that increase in irrigation depths from $50 \%$ to $100 \%$ had no significant effect on CWUE while at 10 days irrigation interval, increase in irrigation depths from $50 \%$ to $75 \%$ revealed a significant increase in CWUE, but further increase to $100 \%$ irrigation depth had no any significant effect on CWUE. When irrigation depth was fixed, all the irrigation depths revealed that increase in irrigation interval from 7 day to 10 day had no significant effect on CWUE. Further increase to 13 days irrigation interval shows a significant reduction in CWUE at $75 \%$ and $100 \%$ irrigation depths while $50 \%$ irrigation depths had no significant effect on the CWUE. The CWUE was at $\mathrm{I}_{10} \mathrm{D}_{75} \%$ with $0.790 \mathrm{~kg} / \mathrm{m}^{3}$ while the least was at $\mathrm{I}_{13} \mathrm{D}_{75 \%}$ with $0.560 \mathrm{~kg} / \mathrm{m}^{3}$.
Effect of irrigation depths and irrigation intervals on irrigation water use efficiency

Table 4 shows the effect of irrigation depths and irrigation intervals on Irrigation Water Use Efficiency (IWUE) which was significant at $\mathrm{P}<0.01$ levels. Increase in irrigation depths from $50 \%$ to $75 \%$ resulted in significant increased in IWUE while further increase in irrigation depth to $100 \%$ shows no any significant affect on IWUE. Also, increase in irrigation interval from 7 day to 10 day significantly increased the IWUE while further increase in irrigation interval to 13 day significantly reduced the IWUE.

A significant interaction between irrigation depth and irrigation interval on IWUE was observed (Table 5). When irrigation interval was fixed, irrigation intervals at 10 day revealed that increase in irrigation depths from $50 \%$ to $75 \%$ significantly increased the IWUE while it had no any significant effect on IWUE at 7 and 13 days. Further increase to $100 \%$ irrigation revealed that a significant reduction in IWUE at 7 day while 10 day and 13 day irrigation interval had no any significant effect on the IWUE. But when irrigation depth was fixed, irrigation depths at $75 \%$ and $100 \%$ revealed that increase in irrigation interval from 7 day to 10 day significantly increased while irrigation depth at $50 \%$ had no any significant effect on the IWUE. Further increase to 13 day irrigation interval resulted to a significant reduction in IWUE at all the irrigation depth. The IWUE was at $\mathrm{I}_{10} \mathrm{D}_{75 \%}$ with $0.71 \mathrm{~kg} / \mathrm{m}^{3}$ while the least was at $\mathrm{I}_{13} \mathrm{D}_{50 \%}$ with $0.41 \mathrm{~kg} / \mathrm{m}^{3}$. 


\section{DISCUSSION}

The highest maize yield obtained was at $\mathrm{I}_{7} \mathrm{D}_{100} \%$ while the least yield obtained was at $\mathrm{I}_{13} \mathrm{D}_{50 \%}$. The highest yield was due to the adoption of full irrigation, which may be attributed to the fact that higher irrigation depths would provides the crops with adequate moisture in the surface layer in which most of the maize roots exists, thus resulting in better crop nourishment and consequently higher yield. This finding was in agreement with the conclusions of (Yazar et al., (1999); Kara and Biber (2008); Farré and Faci (2009)); they reported that Maize grain yield increased significantly by irrigation water amount and irrigation frequency while the least yield was due to the moisture stress the plants were subjected which reduced dry matter accumulation of vegetative components of maize. Similar evidence was reported by Yang et al., (1994), Ahmed and El Hag (1999), and Ahmed (2002). They stated that, increasing the irrigation intervals resulted to a decrease in yield. The yields obtained in this study agreed with the one reported by other researchers, who had worked on deficit irrigation on maize: Sani et al., (2008) in Samaru (Northern Guinea Savanna) recorded Maize yield between 2.072$3.348 \mathrm{t} / \mathrm{ha}$ and $2.17-3.01 \mathrm{t} / \mathrm{ha}$ in $2009 / 10$ and $2010 / 11$ seasons respectively; Iyanda et al., (2014) recorded maize yield of about 2.3t/ha, 2.8t/ha and $0.5 \mathrm{t} / \mathrm{ha}$ in Samaru, Ibadan and Maiduguri respectively while FAO, 2012 recorded maize of 1.7t/ha. Institute for Agricultural Research, Samaru reported a potential yield of $4.0 \mathrm{t} / \mathrm{ha}$ for the same crop (SAMMAZ 29) which is higher than the one obtained in this study $(3.58 \mathrm{t} / \mathrm{ha})$ which may be attributed to the difference in the climatic conditions and in the growing period duration.

The crop water use efficiency was recorded to range from 0.56 $-0.79 \mathrm{~kg} / \mathrm{m}^{3}$, with the least value found in treatment $\mathrm{I}_{13} \mathrm{D}_{75 \%}$ and the highest value obtained in treatment $\mathrm{I}_{10} \mathrm{D}_{75 \%}$. This validated FAO (1995), that irrigation regime that provide soil moisture for maximum crop growth and yield per unit area would be unlikely to produce maximum output per unit of water (WUE). The results obtained in this study fall within the ranges stated by Sani et al., (2008) and FAO (2013) as $0.6-0.8 \mathrm{~kg} / \mathrm{m}^{3}$.

The irrigation water use efficiency was recorded to range from $0.41-0.71 \mathrm{~kg} / \mathrm{m}^{3}$, with the least value found in treatment $\mathrm{I}_{13} \mathrm{D}_{50 \%}$ and the highest value obtained in treatment $\mathrm{I}_{10} \mathrm{D}_{75 \%}$. These result agreed with Igbadun (2012), which recorded IWUE at Samaru (Northern Guinea Savanna) to vary from 0.42 to $0.55 \mathrm{~kg} / \mathrm{m}^{3}$ in $2009 / 10$ season and 0.45 to $0.61 \mathrm{~kg} / \mathrm{m}^{3}$ in 2010/11 seasons respectively while Kuscu et al., (2013) reported IWUE to vary from $0.50-1.59 \mathrm{~kg} / \mathrm{m}^{3}$ in 2007 and 0.41 $1.82 \mathrm{~kg} / \mathrm{m}^{3}$ in 2008 seasons respectively.

\section{CONCLUSIONS}

Adoption of deficit irrigation resulted to greater water use efficiency. Maximum CWUE and IWUE were obtained when the crops were stressed at $\mathrm{I}_{10} \mathrm{D}_{75} \%$, thus saving about $48.3 \%$ of irrigation water (amounted to $329 \mathrm{~mm}$ ) with reference to control $\left(\mathrm{I}_{7} \mathrm{D}_{100 \%}\right)$ which causes a yield reduction of about $19 \%$ (amounted to $680 \mathrm{~kg} / \mathrm{ha}$ ). It was concluded from the study that optimum yield of maize can be obtained when crop is irrigated after every 10 days with $75 \%$ replacement of total available water content $\left(\mathrm{I}_{7} \mathrm{D}_{75 \%}\right)$.

\section{REFERENCES}

Ahmed, F. E. (2002). Water Stress and Genotype Effects on Yield and Seed Quality in Maize(Zea mays L.). University of Khartoum Journal of Agricultural Sciences 10(2), 213-223.

Ahmed, F. E. and H. E., El Hag (1999). Effect of Watering Intervals on Yield and Yield Components of Two Maize (Zea mays L.) Cultivars Grown in Summer and Winter. University of Khartoum Journal of Agricultural Sciences 7(1), 20-33.

Andreas, P. S. and F., Karen (2002). Crop Water Requirements and irrigation Scheduling. Irrigation Manual. Module 4

Bekele, S. and K. Tilahun, (2007). Regulated deficit irrigation scheduling of onion in a semiarid region of Ethiopia. Agricultural Water Management, 89:148-152.

Crãciun Ioana, and M., Crãciun (1993). Reacpia unor hibrizi de porumb la stresul hidric, Analele I.C.C.P.T., vol LX: 101114

FAO. (1979). Yield response to water. by J. Doorenbos \& A.H. Kassam. Irrigation and Drainage Paper No.33. FAO, Rome Irrigation and Drainage Paper 33. Rome, Italy.

FAO. (1995). CROPWAT and CLIMWAT software packages. Rome, Italy

FAO. (2012). Crop yield response to water (Irrigation and drainage paper 66) by Pasquale Steduto,Theodore C. Hsiao,Elias

Fereres and Dirk Raes. Food And Agriculture Organization of the United Nations Rome, 2012 FAO, Rome

FAO. (2013). Water Development and Management Unit: Crop Water Information for Maize.

Farré, I. and J. M., Faci (2009). Deficit Irrigation in maize for reducing agricultural water use in a Mediterranean environment. Agric. Water Manage. 96: 383-394.

Howell T. A. (2003). Irrigation Efficiency. United States Department of Agriculture (USDA), Bushland, Texas, U.S.A.

Hussaini, M. A., M. K., Othman, M. F., Ishyaku and A. M. Falaki (2008). Response of Cowpea (Vigna unguiculata L. Walp) to Methods and Levels of Irrigation Under Varying

Fertilizer Levels in a Semi-arid Region of Nigeria. Journal of Food, Agriculture \& Environment Vol.2 (3\&4) : 137-140

Igbadun, H.E. (2012). Estimation of Crop Water Use of RainFed Maize and Groundnut Using Min- Lysimeters. Pacific Journal of Science and Technology. 13(1):527- 535.

Iyanda R.A., G., Pranuthi, S. K., Dubey, S. K., Tripathi (2014). Use of dssat ceres maize model as a tool of identifying potential zones for maize production in Nigeria .Int. J. Agric. Pol. Res. 2(2):069 -075

Jaliya, M. M., A. M. Falaki, M. Mahmud and Y.A. Sani (2008). Effect of Sowing Date and NPK Fertilizer Rate on Yield and Yield Components of Quality Protein Maize (Zea Mays L.) 
Jin M. G., Zhang R. Q. and Gao Y. F., (1999) Temporal and spatial soil water management: A case study in the Heiloonggang Region, PR China. Agricultural Water Management 42: 173-187.

Kara, T. and C. Biber, (2008). Irrigation frequencies and corn (Zea mays L.) yield relation in Northern Turkey. Pakistan J. Bio. Sci. 11(1): 123-126

Karam, F., J. Breidy and C. Stephan, J. Rouphael, (2003). Evapotranspiration, yield and water use efficiency of drip irrigated corn in the Bekaa Valley of Lebanon. Agric. 137. Water Manage. 63(2): 125-

Kuscu Hayrettin , Abdullah Karasu, Mehmet OZ, Ali Osman Demi, İlhan Turgut (2013). Effect of irrigation amounts applied with drip irrigation on maize evapotranspiration, yield, water use efficiency, and net return in a sub-humid climate Majnooni-

Heris A., Hossein N. A., Ashraf S. A.(2014). Effects of deficit irrigation on the yield, yield components, water and irrigation water use efficiency of spring canola. Journal of Biodiversity and Environmental Sciencce (JBES). ISSN: 2220-6663 (print) 2222-3045 (online). Vol. 5, No 2, p. 44-53, 2014

Mani H. and S. A. Dadari (2003). Growth and yield analysis of irrigated popcorn (zea mays evarta) Grown in kadawa as affected by sowing date and intra-row Spacing, using correlation co-efficient. Asset Series A (2003) 3

Merriam, J. L. and J. Keller (1978). Irrigation system evaluation: A guide for management. Dept. of Agric. and Irrig. Engg. Utah State Univ. USA

Michael, A. M. (1999) Irrigation theory and practice. Vikas Publishing House, New Delhi, India. pp 530-539.

Michael A.M. 1978. Irrigation theory and practice. $1^{\text {st }}$ Ed., Vikas Publishing House Pvt Ltd., New Delhi. pp. 510-511.
Michael, A. M. (2009). Irrigation theory and practice. Second edition Netafim USA (2010). Manual for Corn Production Using Sub-Surface Drip Irrigation

Ramesh G. and T. Nadanassababady (2005). Impact of herbicides on weeds and soil ecosystem of rainfed maize (zea mays l.). Indian J. Agric. Res., 39 (1) : 31 - 36. 2005

Sani B. M., K. O. Oluwasemire and H. I. Mohammed (2008). Effect of irrigation and Plant density on the growth, yield and water use efficiency of early maize in the Nigerian Savanna. Vol.3, No.2.ARPN Journal of Agricultural and Biological Science (c) 2006-2008 Asian Research Publishing Network (ARPN). www.arpnjournals.com

Smith M. and Kivumbi D. (2002). Use of the FAO CROPWAT model in deficit irrigation studies, pg 17. In: deficit irrigation practices Land and Water Development Division, Food and Agriculture Organization, Rome, Italy L.K. Heng, Joint FAO/IAEA Division, International Atomic Energy Agency, Vienna, Austria

Tariq J. A. and K. Usman (2009). Regulated deficit irrigation scheduling of maize crop. Sarhad J. Agric. 25(3):441.450

Yang, C.M.; M. J. Fan and W. M. Hsiang (1994). Growth and Yield Responses of Maize to Soil Water Deficits. Field Crops Abstract 47(1), 167.

Yahya Parvizi, Mohammad Ghaitori, Karim Nazari and Masoome Vahedi, (2011) Evaluation the effects of organic Fertilizer and irrigation interval on Water need, water use efficiency, and Quality and quantity of maize yield ICID 21st International Congress on Irrigation and Drainage, 15-23 October 2011, Tehran, Iran.

Yazar, A., T.A. Howell, D.A. Dusek, K.S. Copeland, (1999). Evaluation of crop water stress index for LEPA irrigated corn. Irrig. Sci. 18, 171-180. 